\title{
Effects of the toxic dinoflagellate Alexandrium fundyense on the copepod Acartia hudsonica: a test of the mechanisms that reduce ingestion rates
}

\author{
Sean P. Colin ${ }^{1,2, *}$, Hans G. Dam ${ }^{1}$ \\ ${ }^{1}$ Department of Marine Sciences, University of Connecticut, Groton, Connecticut 06340-6097, USA \\ ${ }^{2}$ Present address: Biology Department, Roger Williams University, One Old Ferry Road, Bristol, Rhode Island 02809, USA
}

\begin{abstract}
Reduced grazing on harmful algal bloom species has been attributed to both the feeding deterrence and toxicity of the algae. Both toxic and deterrent effects of dinoflagellates of the genus Alexandrium, which contain toxins that cause paralytic shellfish poisoning, have been reported on different copepod species. We examined how toxin-containing Alexandrium fundyense affected ingestion rates of 2 geographically distinct Acartia hudsonica (Copepoda: Calanoida) populations over short timescales. The copepod population from Great Bay, New Jersey, has never been exposed to blooms of toxic A. fundyense, whereas the population from Casco Bay, Maine, has experienced regular blooms of the highly toxic dinoflagellate for decades. Our goals were to examine the mechanisms by which toxin-containing Alexandrium reduced the ingestion rates of copepods and determine whether the mechanisms were related to the exposure history of copepod populations. Copepods were fed, for $48 \mathrm{~h}$ durations, sole diets of toxin-containing A. fundyense, non-toxin containing Alexandrium tamarense and the green flagellate Tetraselmis sp. (not known to have toxic effects) and different mixtures of each (70\% Alexandrium/30\% Tetraselmis sp., 40/60, 20/80). Changes in ingestion rates over time were determined by measuring ingestion at different time intervals $(3,6,12,24,48 \mathrm{~h})$ over the $48 \mathrm{~h}$ period using $3 \mathrm{~h}$ incubations. The naïve copepods from New Jersey initially ingested toxin-containing A. fundyense, in both sole and mixed diets, at high rates followed by decreases in ingestion over time. By $24 \mathrm{~h}$, their total ingestion rates were near zero. The decreases in ingestion rates, which were not due to prey selection, were also accompanied by reduced respiration rates. In contrast, none of these effects were observed when the New Jersey copepods fed on non-toxic $A$. tamarense. Additionally, feeding rates of historically exposed copepods from Maine were not affected by the toxin-containing $A$. fundyense diets. These observations are consistent with the hypothesis that toxic $A$. fundyense physiologically incapacitated the copepods from New Jersey but not those from Maine. Such toxic effects, as opposed to deterrence effects, can have profound implications on the grazers' ability to control harmful algal blooms.
\end{abstract}

KEY WORDS: Copepod $\cdot$ Toxic dinoflagellate $\cdot$ Toxicity $\cdot$ Resistance $\cdot$ Ingestion rate $\cdot$ Physiological incapacitation $\cdot$ Feeding deterrence

\section{INTRODUCTION}

There is mounting evidence that harmful algal blooms (HABs) are spreading geographically and occurring more frequently (Hallegraeff 1993). For instance, this is the case with the dinoflagellate genus Alexandrium, responsible for paralytic shellfish poisoning (PSP), whose distribution has increased and which has bloomed more frequently in recent years (Anderson 1997). Since blooms only occur in the presence of relaxed grazing pressure, it is important to understand how harmful algae affect zooplankton feeding rates.

It has been shown that the effect of Alexandrium spp. on the feeding rates of grazers is dependent upon the history of the exposure of the grazer popu- 
Table 1. Results of studies that compared effects of sole versus mixed diets of putatively harmful algal species on copepod feeding rates. Feeding rates: $(-)$ rates lower than on mixed or $100 \%$ control species; $(+)$ rates greater than sole diet or not different from control species. Prey selection: symbols indicate that the alga was selected for (+) or against (-) (but still ingested at low rates); (o) test alga was not ingested at all when present in a mixed diet $;+$ in both columns indicates no preference for test or control alga. Effects: $(-)$ effect identified under 'Type' was worse than mixed or control diet; (+) effect was better than sole diet or not different from control diet. Blank entry: data not reported. *Study measured egestion. NJ: New Jersey; ME: Maine

\begin{tabular}{|c|c|c|c|c|c|c|c|c|c|}
\hline \multirow{2}{*}{$\begin{array}{l}\text { Agal species } \\
\text { Test species/ } \\
\text { control species }\end{array}$} & \multirow[t]{2}{*}{ Copepod species } & \multicolumn{2}{|c|}{ Feeding rates } & \multicolumn{2}{|c|}{ Prey selection } & \multicolumn{2}{|c|}{ Effects } & \multirow[t]{2}{*}{ Type } & \multirow[t]{2}{*}{ Source } \\
\hline & & $\begin{array}{l}\text { Sole } \\
\text { diet }\end{array}$ & $\begin{array}{l}\text { Mixed } \\
\text { diet }\end{array}$ & $\begin{array}{l}\text { Test } \\
\text { alga }\end{array}$ & $\begin{array}{l}\text { Control } \\
\text { alga }\end{array}$ & $\begin{array}{l}\text { Sole } \\
\text { diet }\end{array}$ & $\begin{array}{c}\text { Mixed } \\
\text { diet }\end{array}$ & & \\
\hline $\begin{array}{l}\text { Nodularia sp./ } \\
\text { Brachiomonas submarina }\end{array}$ & Acartia bifilosa & - & + & & & & & & Engstrom et al. (2000) \\
\hline $\begin{array}{l}\text { Protoceratium reticulatum/ } \\
\text { Gyrodinium resplendens }\end{array}$ & Calanus pacificus & - & + & - & + & & & & Huntley et al. (1986) \\
\hline $\begin{array}{l}\text { Scrippsiella trochoidea/ } \\
\text { G. resplendens }\end{array}$ & C. pacificus & - & + & - & + & & & & Huntley et al. (1986) \\
\hline $\begin{array}{l}\text { Alexandrium excavatum/ } \\
\text { Thalassiosira weissflogii }\end{array}$ & C. finmarchicus & - & + & - & + & & & & Turriff et al. (1995) \\
\hline $\begin{array}{l}\text { A. fundyense/ } \\
\text { A. tamarense }\end{array}$ & A. tonsa & - & + & - & + & - & + & & Teegarden (1999) \\
\hline $\begin{array}{l}\text { A. fundyense/ } \\
\text { A. tamarense }\end{array}$ & $\begin{array}{l}\text { Centropage } \\
\text { hamatus }\end{array}$ & - & + & - & + & + & + & & Teegarden (1999) \\
\hline $\begin{array}{l}\text { Heterosigma carterae/ } \\
\text { Tetraselmis sp. }\end{array}$ & A. tonsa & - & + & + & + & - & + & Growth & Colin \& Dam (2002b) \\
\hline $\begin{array}{l}\text { Phaeodactylum tricornutum/ } \\
\text { Tetraselmis sp. }\end{array}$ & A.tonsa & - & + & - & + & - & + & Growth & Colin \& Dam (2002b) \\
\hline $\begin{array}{l}\text { Oscillatoria rubescens/ } \\
\text { Chlamydomonas }\end{array}$ & Diaptomas birgei & - & + & o & + & & & & Demott \& Moxter (1991) \\
\hline $\begin{array}{l}\text { O. agardhii/ } \\
\text { Chlamydomonas }\end{array}$ & D. birgei & - & + & - & + & & & & Demott \& Moxter (1991) \\
\hline Anabaena affinis/ & D. minutus & + & - & + & & & & & Kirk \& Gilbert (1992) \\
\hline $\begin{array}{l}\text { Prymnesium patelliferum / } \\
\text { B. submarina }\end{array}$ & Eurytemora affinis & - & + & + & - & - & + & Mortality & Koski et al. (1999) \\
\hline $\begin{array}{l}\text { P. patelliferum/ } \\
\text { Pseudopedinella elastica }\end{array}$ & E. affinis & - & - & - & - & - & + & Mortality & Koski et al. (1999) \\
\hline $\begin{array}{l}\text { P. patelliferum/ } \\
\text { Rhodomonas baltica }\end{array}$ & A. clausi ${ }^{*}$ & - & - & - & - & - & - & Growth & Nejstgaard \& Solberg (1996) \\
\hline $\begin{array}{l}\text { Alexandrium sp./ } \\
\text { Tetraselmis sp. }\end{array}$ & A. tonsa & - & - & - & - & - & - & Ingestion & Colin \& Dam (2002a) \\
\hline $\begin{array}{l}\text { Alexandrium sp./ } \\
\text { Tetraselmis sp. }\end{array}$ & NJ A. hudsonica & - & - & - & - & - & - & Ingestion & This study \\
\hline $\begin{array}{l}\text { Alexandrium sp./ } \\
\text { Tetraselmis sp. }\end{array}$ & ME A. hudsonica & + & + & + & + & + & + & & This study \\
\hline
\end{tabular}

lations to Alexandrium blooms; for instance, toxincontaining Alexandrium spp. reduced the feeding rates of grazers from populations naïve to Alexandrium blooms, but not the rates of grazers from populations that are regularly exposed to the blooms (Colin \& Dam 2002a). To better predict how spreading Alexandrium blooms may impact zooplankton grazing in different regions, we must understand the mechanisms that determine the feeding rates of grazers on Alexandrium.

It has been suggested that Alexandrium spp. reduces the feeding rates of grazers through both feeding deterrence (Turriff et al. 1995, Teegarden \& Cembella 1996, Shaw et al. 1997, Teegarden 1999) and toxic effects (Huntley et al. 1986, Ives 1987). Deterrents and toxins reduce the feeding activity via different mecha- nisms. Feeding deterrents are compounds found in algae that are detected by the grazer and cause the grazer to behaviorally cease feeding or select against that algal species (Shaw et al. 1997). While these algae may contain toxic compounds, if copepods possess the ability to detect and identify a toxic compound in algae, then this is an adaptive trait that enables the grazer to avoid potentially harmful foods prior to ingesting harmful amounts (Taylor 1986). Thus, in such a case, the algae deter the feeding activity of the grazer without inducing a toxic response. Several copepod species appear to have this type of adaptive response to toxin-containing Alexandrium spp. (Turriff et al. 1995, Teegarden 1999). Accordingly, these copepods select against Alexandrium spp. when fed diets containing the dinoflagellate (Turriff et al. 1995, Tee- 
garden 1999). In contrast, toxic algae contain compounds that, once ingested, reduce the grazer's ability to feed (Walker et al. 2001). Therefore, ingestion of toxic algal cells is required to induce a toxic response.

Many studies examining the effects of HAB species on grazers used the test alga as the sole food source; however, it is not possible to distinguish between deterrent and toxic effects with experiments using only sole-food diets (Colin \& Dam 2002b). A survey of the studies that have used both sole and mixed diets to examine the effects of different algal species on copepod grazing rates revealed that most of the tested algae which reduced copepod feeding only did so when provided as the sole food (Table 1). Copepods generally resume normal feeding rates, relative to a control diet, when the tested algae are part of a mixed diet. These algae meet the definition of having a feeding deterrent effect because they only inhibit feeding when provided solely, and they do not cause any detrimental effects on copepods when provided in a mixed diet. In contrast, because the effects of toxic algae are dose-dependent, they reduce feeding rates when presented as either a sole or mixed diet (Table 1; Nejstgaard \& Solberg 1996, Jónasdóttir et al. 1998, Colin \& Dam 2002b).

Understanding which mechanism is responsible for the reduced feeding rates on Alexandrium is important, since natural blooms of Alexandrium are seldom monoalgal, and as a result, grazers in situ would always encounter Alexandrium as part of a mixed diet (Turner \& Anderson 1983, Watras et al. 1985, Teegarden et al. 2001). Therefore, depending on the concentration of toxic Alexandrium, the feeding activity of copepods during Alexandrium blooms will depend upon whether Alexandrium has toxic or deterrent effects on grazers.
The goal of this study was to examine the role of feeding deterrence and toxicity-i.e. physiological incapacitation - in determining the feeding rates of naïve and historically exposed copepods on toxincontaining Alexandrium fundyense. We measured short-term changes in the ingestion rate and prey selection of the naïve Acartia hudsonica population from Great Bay, New Jersey (NJ), and the exposed population from Casco Bay, Maine (ME). In addition, we measured the effects of toxin-containing $A$. fundyense on the respiration rate of $A$. hudsonica from New Jersey. According to other observations of copepods feeding on sole and mixed algal diets, a reduction in the total ingestion rates of $A$. hudsonica can be attributed to feeding deterrence if (1) it is only observed when the copepods are fed sole diets or (2) it is due to prey selection against $A$. fundyense in mixed diets. In contrast, it is strong evidence that $A$. fundyense has toxic effects on $A$. hudsonica if reduced feeding rates are (1) observed after initial ingestion of $A$. fundyense cells; (2) observed in all diets containing $A$. fundyense, both sole and mixed; (3) not the result of prey selection; and (4) associated with physiological changes-e.g. respiration - in the copepods. All of these conditions must be met for us to be confident that A. fundyense produced toxic effects on A. hudsonica.

\section{MATERIALS AND METHODS}

Collection and culture of organisms. The algal strains used in this study were toxin-containing Alexandrium fundyense (NB-05, see Table 2 for toxin content), non-toxin-containing Alexandrium tamarense (ATSW01-1) and non-toxic green flagellate Tetraselmis sp. (Table 2). All diets used in the experiments

Table 2. Experimental diets. Means of the equivalent spherical diameter (ESD), carbon content and toxin content (for Alexandrium strains) at the time of the experiments. STXeq.: saxitoxin equivalent

\begin{tabular}{|c|c|c|c|c|}
\hline $\begin{array}{l}\text { Experiment } \\
\text { Strain name }\end{array}$ & $\begin{array}{c}\text { Alexandrium } \\
(\mu \mathrm{m})\left(\mu \mathrm{g} \mathrm{C} \text { cell }^{-1}\right)\end{array}$ & $\begin{array}{c}\text { ESD } \\
\text { (pg STXeq. cell }{ }^{-1} \text { ) }\end{array}$ & Carbon content & Toxin content \\
\hline \multicolumn{5}{|l|}{ Sole food } \\
\hline Alexandrium fundyense & NB-05 & 21.6 & $1.51 \times 10^{-3}$ & 11.4 \\
\hline Tetraselmis sp. & & 7.6 & $4.1 \times 10^{-5}$ & \\
\hline \multicolumn{5}{|l|}{ Prey selection } \\
\hline Alexandrium fundyense & NB-05 & 26.7 & $2.8 \times 10^{-3}$ & 21.0 \\
\hline Tetraselmis sp. & & 8 & $4.8 \times 10^{-5}$ & \\
\hline \multicolumn{5}{|l|}{ Non-toxic Alexandrium } \\
\hline Alexandrium tamarense & ATSW01-1 & 23.7 & $2.0 \times 10^{-3}$ & 0.00 \\
\hline Tetraselmis sp. & & 7.4 & $3.8 \times 10^{-5}$ & \\
\hline \multicolumn{5}{|l|}{ Metabolic rate } \\
\hline Alexandrium fundyense & NB-05 & 24.1 & $2.1 \times 10^{-3}$ & 16.1 \\
\hline Tetraselmis sp. & & 7.4 & $3.8 \times 10^{-5}$ & \\
\hline
\end{tabular}


were from cultures maintained in exponential growth phase, by weekly dilution with F/2 medium (Guillard 1975), and kept at $15^{\circ} \mathrm{C}$ and in a $12: 12 \mathrm{~h}$ light:dark regime. Culture illumination, $50 \mu \mathrm{mol}$ photon $\mathrm{m}^{-2} \mathrm{~s}^{-1}$, was provided by cool-white fluorescent tubes.

Before each experiment, replicate aliquots of the Alexandrium spp. cultures were collected for toxin extraction (Table 2). Toxins were extracted according to Anderson et al. (1994) and analyzed by HPLC (highperformance liquid chromatography) using methods of Oshima et al. (1989) in our laboratory (STX standards provided by NRC, Halifax, Canada). Of the suite of saxitoxins present in Alexandrium spp., we quantified the most potent-saxitoxin (STX), neosaxitoxin (NEO), and gonyautoxins I-IV (GTX1-4). Analysis of this suite of toxins was adequate for this study since toxin analyses were performed only to confirm that the toxic strains were indeed toxic and that the non-toxic strains were non-toxic. Additionally, the toxins that were not analyzed, the B and C saxitoxins and decarbamoyl saxitoxins, have been found to be the least potent of the toxins (Schantz 1986, Indrasena \& Gill 1999).

Populations of Acartia hudsonica were collected from Casco Bay, ME, and Great Bay, NJ, using a $200 \mu \mathrm{m}$ mesh plankton net (Colin \& Dam 2002a). Upon collection, copepods were transported to the laboratory within $24 \mathrm{~h}$. Cohorts of 1000 to 1500 individuals from each population were separated and cultured under identical conditions following Feinberg \& Dam (1998). This method proved to be an efficient and gentle way to maintain separately, for over a year ( $\sim 11$ generations), the different copepod populations at densities of 500 to $1000 \mathrm{ind}$. per $20 \mathrm{l}$. One concern of maintaining cultures for long periods of time is that their small population sizes may cause genetic drift and decreased genetic variation within the populations. To sustain natural levels of genetic variation, we maintained high copepod densities within the cultures and refreshed the cultures with new individuals from the field each season when A. hudsonica was present in the water column.

The cultures were maintained at 12 to $14^{\circ} \mathrm{C}$, in a 12:12 $\mathrm{h}$ light:dark regime and on a mixed diet. The standard diet consisted of Thalassiosira weissflogii, Isochrysis galbana, and Rhodomonas lens and was kept at a near saturating concentration of 400 to $500 \mu \mathrm{g} \mathrm{C} \mathrm{l}^{-1}$ by replenishing the amount every other day. Rearing all of the copepod populations at the same temperature, light and food regimes for several generations eliminated both maternal effects and environmental variance. This allowed us to attribute the observed differences among populations to genetic variance (Falconer 1996, p. 122-144).

Experiments. Copepod ingestion rates were monitored for $48 \mathrm{~h}$ to determine whether the ingestion rates of the naïve (NJ) and exposed (ME) populations of Acartia hudsonica changed over time when feeding on sole diets of Alexandrium fundyense. Accordingly, we measured the short-term changes in ingestion rates when A. hudsonica females were offered $100 \%$ toxincontaining A. fundyense at $150 \mathrm{\mu g} \mathrm{C}^{-1}$ and a control diet of $100 \%$ Tetraselmis sp. of the same concentration. This food concentration is typically limiting to the ingestion of A. hudsonica and is within the range of concentrations reported during natural Alexandrium sp. blooms (Anderson et al. 1983, Turner \& Anderson 1983, Watras et al. 1985). Prior to each experiment, adult $A$. hudsonica were maintained in cultures under experimental conditions with the standard diet. Then, 170 female copepods were transferred to a large batch in a $4 \mathrm{l}$ beaker with a lightly bubbled diet suspension of $100 \%$ toxin-containing $A$. fundyense or a control diet of $100 \%$ Tetraselmis sp. (this represented $t=0$ ). The original algal concentrations in the batches were maintained by measuring the algal concentration and adding more algae if necessary. Ingestion rates were determined from $3 \mathrm{~h}$ incubations and measured at different times $(t=3,6,12,24,48 \mathrm{~h})$, with $t$ representing the end time of the incubation. To measure ingestion rates, triplicate sets of 7 female and 3 male copepods were removed from the batch and placed into separate $140 \mathrm{ml}$ bottles ( 3 treatments) filled with a new food solution that was identical (concentration and food type) to that of the large batch. Treatment and control ( 2 bottles without copepods) bottles were placed on a plankton wheel rotating at $1.3 \mathrm{rpm}$. At the beginning and end of the incubation period, samples for cell counts were taken and preserved in $0.5 \%$ acid Lugol's solution. Algal concentrations for A. fundyense were determined from microscopic cell counts using the Utermöhl (1958) technique. Cell counts for Tetraselmis sp. were performed using an Elzone ${ }^{\circledR} 280$ Particle Counter, where the algal size distribution used to count cells was determined from initial samples and kept constant for final cell counts. To determine the carbon content of the diets (Table 2), aliquots from the grazing control bottles were filtered onto combusted $\left(500^{\circ} \mathrm{C}, 24 \mathrm{~h}\right) \mathrm{GF} / \mathrm{F}$-filter pads and dried at $60^{\circ} \mathrm{C}$ for several days. Carbon content was determined using a Carlo-Erba EA1108 elemental analyzer. Clearance and ingestion rates were calculated using equations from Frost (1972). Carbon ingestion rates were calculated using the carbon per cell factors listed in Table 2. All experiments were performed in an environmental chamber at $14^{\circ} \mathrm{C}$ and in a $12: 12 \mathrm{~h}$ light:dark regime.

To determine whether prey selection changed over time, we used the same design as the sole-food experiment except that we performed the experiment 5 times (over a $48 \mathrm{~h}$ period), each time using different mixtures of Alexandrium fundyense and Tetraselmis 
sp. (100\% Alexandrium, $70 \%$ Alexandrium/30\% Tetraselmis sp., 40/60, 20/80, 100\% Tetraselmis sp.) at a total food concentration of $250 \mu \mathrm{gC} \mathrm{l}^{-1}$. Since we observed from previous experiments that ingestion by the NJ Acartia hudsonica copepods reached a minimum within $24 \mathrm{~h}$, we used $24 \mathrm{~h}$ experiments to examine changes in ingestion rate. Thus, rates were measured at $t=3,6,12,24 \mathrm{~h}$. Prey selection was then determined using Chesson's alpha index (Chesson 1983). In each experiment there were only 2 food types and copepods depleted less than $20 \%$ of the particles. Accordingly we calculated alpha $(\alpha)$ as

$$
\alpha=\left(r_{i} / p_{i}\right) / \sum\left(r_{i} / p_{i}\right)
$$

where $r_{i}$ is the proportion of $A$. fundyense ingested (based on carbon) and $p_{i}$ is the proportion of food type $i$ (i.e. A. fundyense) in the diet mixture.

To examine whether ingestion rates were reduced by non-toxin containing Alexandrium tamarense, we measured the changes in the ingestion rate of the NJ copepods feeding on mixed diet of $50 \%$ A. tamarense and $50 \%$ Tetraselmis sp. at a total concentration of $250 \mu \mathrm{g} \mathrm{C} \mathrm{l}^{-1}$. The experimental design was identical to the sole-food experiment and the prey-selection experiment.

The experiments were designed to allow for the use of multi-way ANOVA tests to compare the rates among populations and diets and over time. (See the 'Results' for the exact variables that were compared.) In all cases, the ingestion rate was the dependent variable that was compared among the independent variables of diet mixture and time. If significance was determined in 3- or 2-way ANOVA tests, planned 1-way ANOVA and Tukey-Kramer post hoc tests were then performed to determine which diets or times differed. Assumptions of normality and homogeneity of variances were met each time we used the ANOVA test, except in a couple of treatments in which ingestion rates were zero. In those instances, the Kruskal-Wallis non-parametric test was used (Sokal \& Rohlf 1995). Statistical tests were done with Statview ${ }^{\mathrm{TM}}$ software.

To test whether respiration rates changed with ingestion, we measured the oxygen consumption rates of the naïve NJ copepods 6 and $24 \mathrm{~h}$ after being offered different concentrations of Alexandrium fundyense and Tetraselmis sp. or after being placed in $0.2 \mu \mathrm{m}$ filtered seawater (labeled 'Starved'). The temperature $\left(14^{\circ} \mathrm{C}\right)$ was the same as that used for the selection and acclimation experiments. The fed copepods were offered diets containing $50 \%$ A. fundyense $/ 50 \%$ Tetraselmis sp. at a total concentration of $250 \mathrm{\mu g} \mathrm{C}^{-1}$ and $100 \%$ Tetraselmis sp. at 125 and $250 \mu \mathrm{g} \mathrm{C} \mathrm{l}^{-1}$. The copepods used in the different treatments were measured and found not to differ significantly in size (mean dry weight $=5.65 \pm 0.89[\mathrm{SD}] \mu$ copepod $^{-1}$, based on prosome length; Durbin \& Durbin 1978; ANOVA, $\mathrm{df}=3, \mathrm{p}>0.83)$. The preparation of copepods prior to the respiration measurements was made according to Ikeda et al. (2000). Accordingly, after the acclimation period and feeding on $250 \mu \mathrm{g} \mathrm{C} \mathrm{l}^{-1}$ of the standard diet (Thalassiosira weissflogii, Isochrysis galbana, and Rhodomonas lens) for $24 \mathrm{~h}$, copepods were gently removed from the food suspension and rinsed in $0.2 \mu \mathrm{m}$ filtered seawater; they were then gently placed into $1 \mathrm{ml}$ chambers containing the experimental solution. All copepods used for respiration measurements were observed to have pigmented guts, indicating that they had fed during the acclimation period. Triplicate incubations were conducted in $1 \mathrm{ml}$ of filtered seawater for about $1 \mathrm{~h}$ in a water-jacketed liquid-phase respiration chamber with 5 to 6 copepods chamber ${ }^{-1}$. Changes in the oxygen concentration of the seawater were monitored using Hansatech ${ }^{\circledR}$ DW1 liquid-phase oxygen electrode units and recorded on a PC with realtime Hansatech ${ }^{\circledR}$ acquisition software. Contents of the oxygen chamber were mixed before the copepods were added to measure an initial oxygen concentration. No stirring occurred during the incubation to prevent damage to the copepods. At the end of the incubation, stirring of the water was resumed to measure a final oxygen concentration. The maximum decrease in the oxygen concentration over the $1 \mathrm{~h}$ incubation period was $10 \%$. Control incubations without copepods were run to ensure that the observed decreases in oxygen concentration in the chambers were due to the copepods. No decreases in oxygen were measured in control runs. Oxygen consumption was calculated from the decrease in oxygen concentration in the chamber over the incubation time.

\section{RESULTS}

\section{Incapacitation experiments}

In the sole-food experiment, we measured shortterm changes in ingestion rates. The comparison of population versus diet versus time reveals a 3-way interaction (3-way ANOVA: interaction of population [ME vs NJ], diet [Tetraselmis sp. and Alexandrium fundyense] and time; $\mathrm{df}=4, \mathrm{p}=0.008$ ). The comparisons of ingestion rates within each population were consistent with the physiological incapacitation hypothesis. The copepods from New Jersey ingested $A$. fundyense at lower rates than Tetraselmis sp. (2-way ANOVA: comparison between diets; $\mathrm{df}=1, \mathrm{p}=0.002$ ), and these rates differed over time (2-way ANOVA: comparison of times; df $=4, p=0.002$ ). For the $A$. fundyense diet, the NJ copepods initially ingested $A$. fundyense at high rates; however, this was followed by 


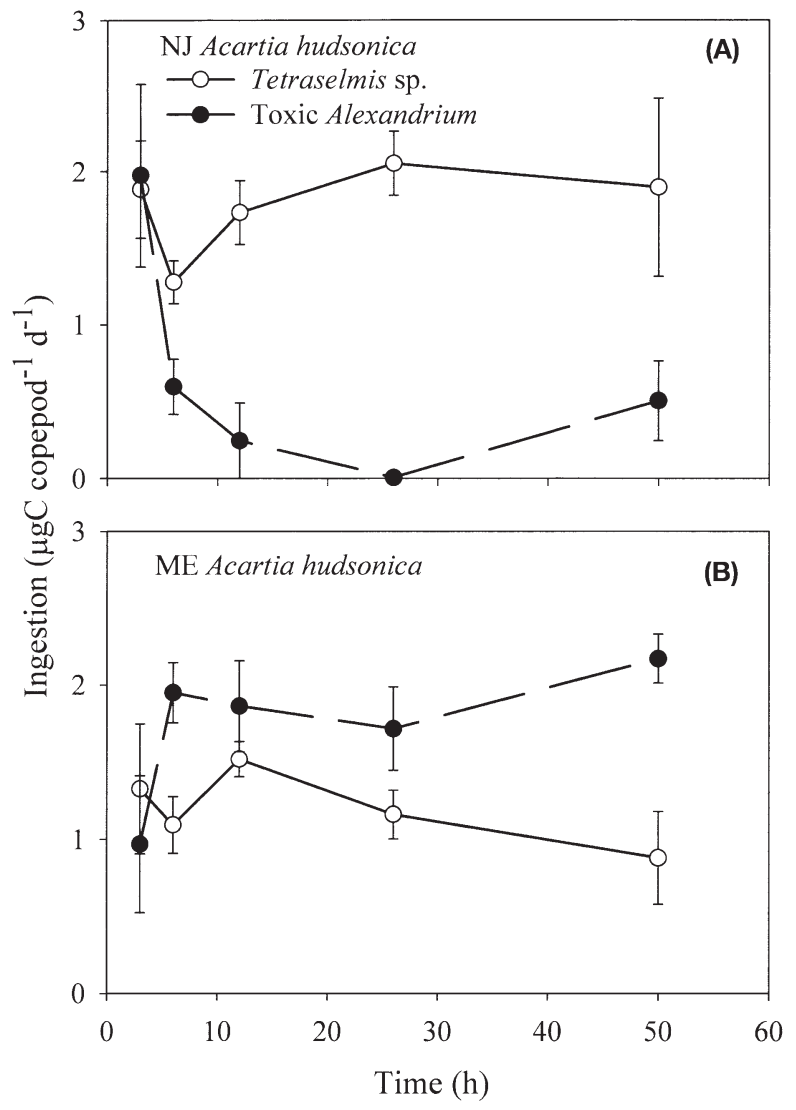

Fig. 1. Sole diet experiments. Mean ingestion rates vs time of (A) New Jersey (NJ), and (B) Maine (ME) female Acartia hudsonica offered sole diets of toxin-containing Alexandrium fundyense and the control alga Tetraselmis sp. measured from $3 \mathrm{~h}$ incubations. Points on plots represent the end time of each $3 \mathrm{~h}$ incubation. Error bars are SEs $(\mathrm{n}=3)$

significant decreases over time (Fig. 1A; 1-way ANOVA: comparisons among times; $\mathrm{df}=4, \mathrm{p}<0.03$ ). In contrast, their ingestion of Tetraselmis sp. did not change over time (Fig. 1A; 1-way ANOVA: comparisons among times; $\mathrm{df}=4, \mathrm{p}=0.5$ ). Additionally, the NJ copepods ingested $A$. fundyense at lower rates than ME copepods (2-way ANOVA: comparison of populations; $\mathrm{df}=1, \mathrm{p}<0.01$ ).

In contrast to what was observed for the NJ copepods, the ingestion rates of the ME copepods feeding on Alexandrium fundyense did not change over time (Fig. 1B; 2-way ANOVA: comparisons of times; $\mathrm{df}=3$, $p=0.1$ ). Furthermore, they ingested $A$. fundyense at higher rates than Tetraselmis sp. (2-way ANOVA: comparison of diets; df $=1, \mathrm{p}=0.003$ ). Accordingly, $A$. fundyense did not appear to have either feeding deterrent or toxic effects on ME Acartia hudsonica.

Also consistent with toxic effects, ingestion rates of the NJ copepods decreased during the first $12 \mathrm{~h}$ on both sole and mixed diets containing Alexandrium fundyense $(100 \%$ A. fundyense, $70 \%$ A. fundyense, $30 \%$ Tetraselmis sp., 40/60, and 20/80) (Fig. 2; 2-way ANOVA, df $=3, \mathrm{p}<0.001$; Tukey-Kramer post hoc test between 3 and $6 \mathrm{~h}$ and 6 and $12 \mathrm{~h}, \mathrm{p}<0.05$ ). After $12 \mathrm{~h}$, total ingestion remained low and unchanged (Fig. 2; Tukey-Kramer post hoc test between 12 and $24 \mathrm{~h}, \mathrm{p}>0.05)$. In addition, ingestion rates were significantly different among food mixtures (comparison among diets excluding the Tetraselmis sp. treatment; 2-way ANOVA, $\mathrm{df}=3, \mathrm{p}=0.027$ ), i.e. ingestion rates were lower when copepods fed on $100 \%$ A. fundyense than on mixtures containing only 20 and $40 \%$ A. fundyense (Tukey-Kramer, $\mathrm{p}<0.05$ ), suggesting a dose response to an increased concentration of A. fundyense.

It appears that these reduced ingestion rates on the mixed diets were not due to changes in prey selection by NJ Acartia hudsonica. In the first $12 \mathrm{~h}$, while $A$. hudsonica ingested both Alexandrium fundyense and Tetraselmis sp. (Fig. 3), the copepods consistently selected A. fundyense over Tetraselmis sp. (Table 3). This is most likely due to the larger cell size of $A$. fundyense (Table 2). Chesson's alpha indices did not change significantly for the 70/30 and 20/80 mixes (Table 3; Kruskal-Wallis non-parametric test for arcsine-transformed indices, $\mathrm{df}=2, \mathrm{p}>0.2$ ), but did change for the 40/60 mix (Table 3, Fig. 3B; KruskalWallis non-parametric test for arcsine-transformed indices, $d f=2, p=0.03$ ). This change in prey selection for the $40 / 60$ mixture treatment does not explain the reduced ingestion, because after $12 \mathrm{~h}$ ingestion rates

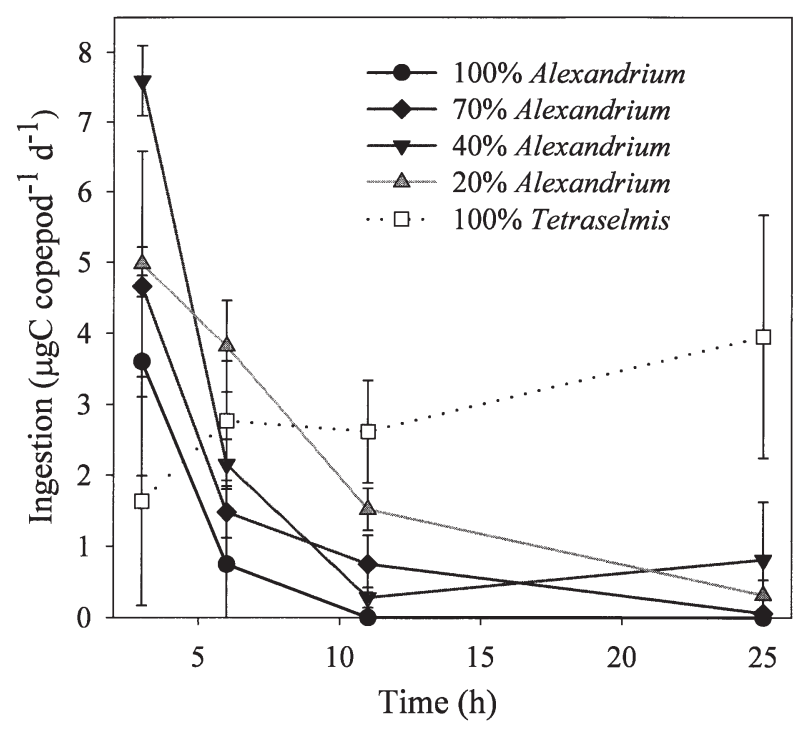

Fig. 2. Mean total ingestion rates vs time of NJ Acartia hudsonica females on sole and mixed diets of Alexandrium fundyense and Tetraselmis sp. Percentages of each alga in the mixture diets were based on carbon. Error bars are SEs $(n=3)$ 
Table 3. Prey selection of NJ Acartia hudsonica vs time. Chesson's alpha indices calculated at different time intervals from diets containing different percentages (based on carbon) of Alexandrium (toxin-containing A. fundyense and non-toxic A. tamarense) and control alga Tetraselmis sp. Values $>0.5(<0.5)$ indicate a preference for Alexandrium (Tetraselmis sp.) in the diet. SE values $(\mathrm{n}=3)$ given in parentheses

\begin{tabular}{|c|c|c|c|c|c|}
\hline \multirow{2}{*}{$\%$ Alexandrium } & \multirow{2}{*}{ 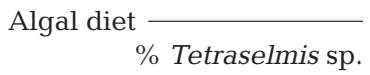 } & \multirow[b]{2}{*}{$3 \mathrm{~h}$} & \multicolumn{2}{|c|}{ - Chesson's alpha index } & \multirow[b]{2}{*}{$25 \mathrm{~h}$} \\
\hline & & & $6 \mathrm{~h}$ & $11 \mathrm{~h}$ & \\
\hline \multicolumn{6}{|l|}{ A. fundyense } \\
\hline 70 & 30 & $0.88(0.17)$ & $0.84(0.27)$ & $0.84(0.23)$ & $0(0.0)$ \\
\hline 40 & 60 & $0.67(0.04)$ & $0.28(0.24)$ & $1(0.0)$ & $1(0.0)$ \\
\hline 20 & 80 & $0.89(0.09)$ & $0.78(0.06)$ & $0.84(0.22)$ & $1(0.0)$ \\
\hline \multicolumn{6}{|l|}{ A. tamarense } \\
\hline 50 & 50 & $0.97(0.18)$ & $0.84(0.10)$ & $0.78(0.16)$ & $0.63(0.11)$ \\
\hline
\end{tabular}

on both prey items were near zero. Overall, no avoidance of $A$. fundyense cells was observed in copepods that were still feeding.

Alexandrium tamarense cells did not have toxic or deterrent effects on the feeding activity of the NJ Acartia hudsonica. The NJ copepods ingested mixture diets containing $50 \%$ A. tamarense/50\% Tetraselmis sp. at high rates. These total rates did not change with time (Fig. 4; 1-way ANOVA: comparisons between times; $\mathrm{df}=3, \mathrm{p}>0.2$ ). Additionally, they selected non-toxic $A$. tamarense over Tetraselmis sp. throughout the experiment (Table 3, Fig. 4; Kruskal-Wallis non-parametric test for arcsine-transformed Chesson's alpha indices, $\mathrm{df}=3, \mathrm{p}=0.17$ ).

To determine whether there were physiological changes associated with the decrease in ingestion, we measured the metabolic rates $\left(\mathrm{O}_{2}\right.$ consumption) of $\mathrm{NJ}$ copepods feeding on diets with and without Alexandrium fundyense at 6 and $24 \mathrm{~h}$. While we did not measure ingestion rates in this experiment, we can infer their feeding activity based on the other experiments in this study. The mean oxygen consumption rates for copepods feeding on diets containing the dinoflagellate were 0.061 and $0.072 \mu \mathrm{O}_{2} \operatorname{copepod}^{-1} \mathrm{~h}^{-1}$ at 6 and $24 \mathrm{~h}$, respectively, as compared to 0.092 and $0.11 \mathrm{\mu l} \mathrm{O}_{2}$ copepod $^{-1} \mathrm{~h}^{-1}$ for copepods feeding on the control diet at the same concentration for those times (Fig. 5). This significant decrease represents a $33 \%$ drop in the oxygen consumption rates of copepods given the toxic diets (Fig. 5; 1-way ANOVA: comparison between $A$. fundyense/Tetraselmis sp. mix and $100 \%$ Tetraselmis sp., both at a concentration of $250 \mu \mathrm{g} \mathrm{C}^{-1}$; df $=1, \mathrm{p}<$ 0.03). Most likely, based on Figs. 1 \& 2, the copepods were still feeding at $6 \mathrm{~h}$. Therefore, the decrease in the ingestion rate of the NJ copepods on A. fundyense was preceded by a decrease in their respiration rate.

The feeding activity of grazers, however, directly affects their respiration rates, due to the energy demands associated with the process of feeding, termed the specific dynamic action (SDA; Kiørboe et al. 1985, Thor 2000). Accordingly, the respiration rates of grazers are reduced when their feeding activity is reduced. Thus, even if Alexandrium fundyense

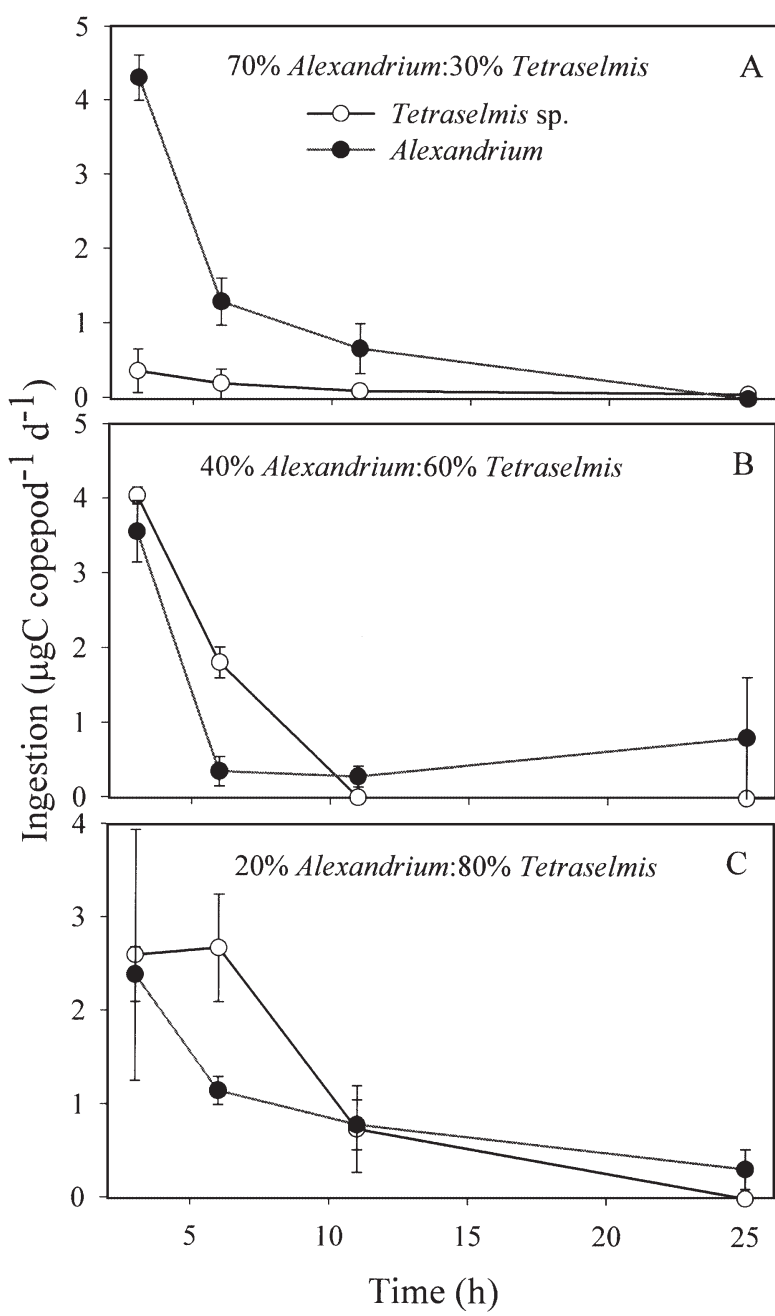

Fig. 3. Mean ingestion rates vs time of NJ Acartia hudsonica females on each component of the Alexandrium fundyense/ Tetraselmis sp. mixed diets. Error bars are SEs $(n=3)$ 


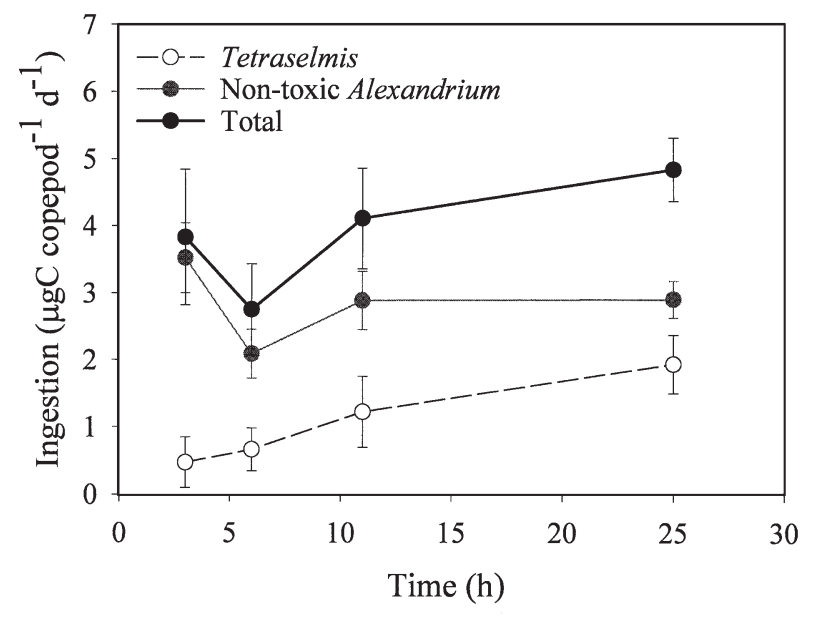

Fig. 4. Mean ingestion rates vs time of NJ Acartia hudsonica females on a $50 \% / 50 \%$ mixed diet containing non-toxic Alexandrium tamarense and Tetraselmis sp. The total ingestion rates and the ingestion rates on the Tetraselmis sp. and $A$. tamarense components are shown. Error bars are SEs $(\mathrm{n}=3)$

only deters feeding activity, we could observe a decrease in the respiration rates of copepods. To ensure that the observed reductions in respiration in the $A$. fundyense treatments was not merely due to a cessation of feeding activity, we examined how respiration rates changed with the reduced feeding activity. To do so we measured the oxygen consumption of Acartia hudsonica both starved and fed Tetraselmis sp. at half the concentration of the A. fundyense diet (125 $\mathrm{\mu g} \mathrm{C} \mathrm{I}^{-1}$; Fig. 5). While we did not measure ingestion rates in this experiment, we know from previous work that at food levels between 0 and $250 \mathrm{\mu g} \mathrm{C} \mathrm{l}^{-1}$, the ingestion rates of $A$. hudsonica change directly with food concentration (authors' unpubl. data). Thus, the SDA and oxygen consumption should decrease as the concentration of Tetraselmis sp. decreases. At $6 \mathrm{~h}$, however, no significant differences in respiration rates were observed between starved copepods and copepods fed the Tetraselmis sp. diets (Tukey-Kramer post hoc test, p > 0.05). In contrast, respiration rate in the A. fundyense treatment was lower than each of the other treatments (Tukey-Kramer post hoc test, p < 0.05). Therefore, the decrease in respiration rate of copepods fed A. fundyense was not due to a decrease in their SDA. By $24 \mathrm{~h}$, respiration rates of both the $A$. fundyense and starved treatments were lower than the Tetraselmis sp. treatment at a concentration of $250 \mu \mathrm{g} \mathrm{C} \mathrm{l^{-1 }}$ (Fig. 5; Tukey-Kramer post hoc test, $\mathrm{p}<0.05$ ). Our oxygen-consumption measurements were similar to other studies measuring the metabolism of A. hudsonica and similarly sized copepods (Ikeda 1985, Thor 2000, Ikeda et al. 2001 and references therein).

\section{DISCUSSION}

\section{Feeding deterrence or incapacitation}

Considerable attention has been directed at determining whether toxin-containing Alexandrium spp. reduce grazer feeding rates through feeding deterrence or toxicity (see Turner et al. 1998 for a review of the subject). Toxicity is easily identifiable when it results in the mortality of the grazer, as is the case with algal toxins such as domoic acid (Shaw et al. 1997). Sublethal toxic effects can include reduced egg viability (diatom diet: Ban et al. 1997, Miralto \& Poulet 1995; dinoflagellate diet: Frangópulos et al. 2000) and reduced feeding (Ives 1985, 1987, Teegarden 1999, Colin \& Dam 2002b). More subtle toxic effects, such as those that reduce feeding activity in zooplankton grazers, are difficult to distinguish from feeding-deterrent effects. This issue is further complicated by the use of

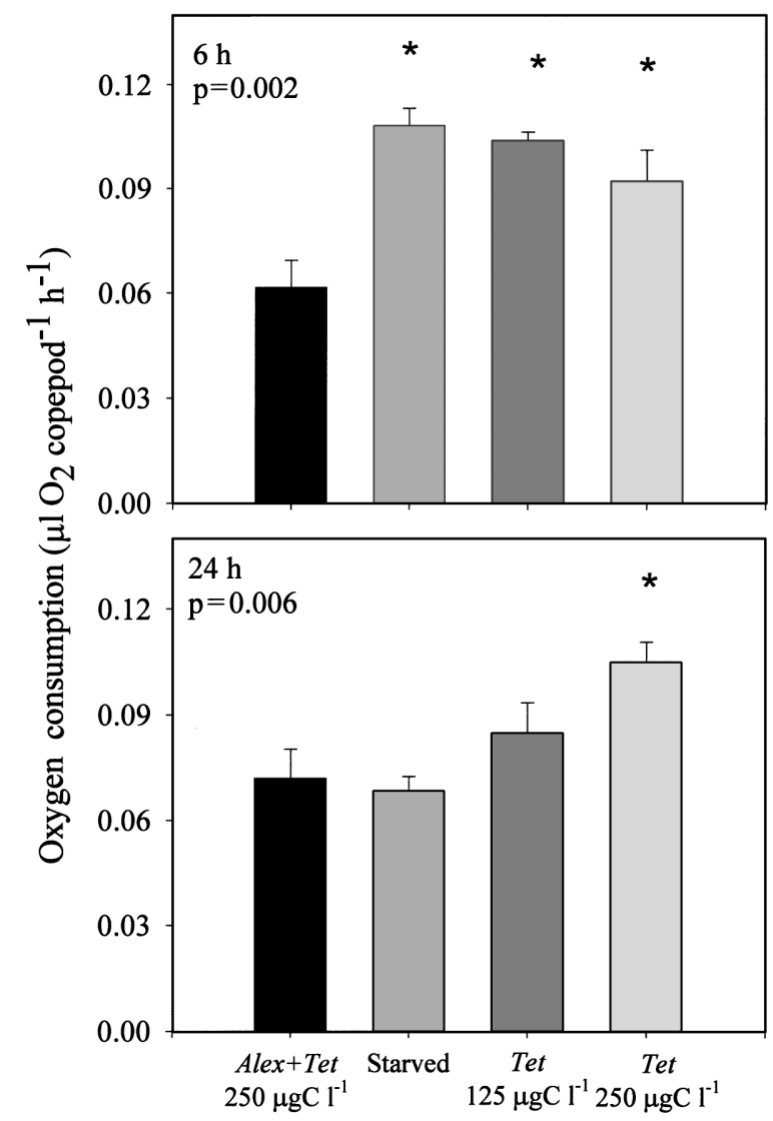

Fig. 5. Mean oxygen consumption rates of NJ Acartia hudsonica females fed a 50\%/50\% mixed diet, starved or fed sole diets of Tetraselmis sp. for 6 and $24 \mathrm{~h}$. Food concentrations for each experiment are shown. p-values are from a 1-way ANOVA, $d f=1$. Error bars are SEs $(n=3)$. Asterisks indicate treatment significantly different from the Alexandrium fundyense + Tetraselmis sp. treatment at $250 \mu \mathrm{g} \mathrm{C}^{-1}$ (TukeyKramer, $\mathrm{p}<0.05$ ) 
different zooplankton species in previous studies that examined the effects of toxin-containing Alexandrium spp. on grazers. It has been well documented that the toxic Alexandrium-grazer relationship is speciesspecific (Teegarden \& Cembella 1996, Turner et al. 1998, Teegarden 1999). Furthermore, within a species the effects are population-specific and dependent upon the evolutionary history (historical exposure) of the different populations to the phytoplankter (Colin \& Dam 2002a). The present study further confirmed the observations of Colin \& Dam (2002a) that A. fundyense had negative effects on the ingestion rates of the naïve Great Bay, NJ, Acartia hudsonica population, while we observed no effect on the ingestion rates for the exposed Casco Bay, ME, population (Fig. 1).

The purpose of this study was to discern the mechanism responsible for the reduced feeding rates of the naïve NJ Acartia hudsonica copepods on Alexandrium fundyense. After initially eating A. fundyense, the NJ copepods decreased their ingestion rates to near zero within $12 \mathrm{~h}$ (Fig. 1A), and the decrease was related to the amount of $A$. fundyense in the diet (Fig. 2). The decrease in ingestion rate could not be explained by prey selection (Table 3, Fig. 3); and a 30\% drop in metabolic rate was associated with the decrease in ingestion rate (Fig. 5). We argue that all of these observations are consistent with toxic effects of $A$. fundyense.

When provided solely, many algal species deter copepods from further feeding (Table 1). However, copepods are not deterred from feeding when these same algal species are mixed with a control food item. Instead, they resume feeding at normal ingestion rates by simply selecting against the deterrent algal species or feeding indiscriminately (Table 1). As a result, the direct and indirect effects of feeding deterrents (e.g. reduced growth) are only observed when the copepods are feeding solely on the deterrent algae (Table 1). The effects of Alexandrium fundyense on the NJ Acartia hudsonica were not consistent with observations for diets containing feeding deterrents.

Reduced feeding activity is also a common result of sublethal toxic effects, and it is often the indirect result of a physiological effect, e.g. neurological impairment (Walker et al. 2001). Since toxic effects are directly related to the dose (in our case, the amount of toxin ingested), they are not dependent on whether the toxic algae are provided solely or in a mixture. In our study the NJ copepods reduced their feeding rates on all diets containing Alexandrium fundyense, and the magnitude of the decrease was related to the amount of $A$. fundyense in the diet (Fig. 2). This toxic effect is most likely attributed to the saxitoxins contained in $A$. fundyense cells. Since saxitoxins are neurotoxins, it is hypothesized that the copepods are physiologically impaired by ingesting $A$. fundyense, which decreases their ability to feed effectively (Ives 1987).

The physiological incapacitation hypothesis is also supported by the respiration rates of NJ Acartia hudsonica, which decreased $30 \%$ when the copepods were fed Alexandrium fundyense (Fig. 5). These changes are not the result of reduced SDA of the copepods feeding on $A$. fundyense; rather, they are due to another physiological effect of the toxic diet. While it is not known how saxitoxins work to incapacitate invertebrates, they have been shown to affect the respiration rates of diverse intoxicated invertebrates (copepods: Sykes \& Huntley 1987; soft-shelled clams: Bricelj et al. 2000). A. fundyense similarly reduced the respiration rates of naïve populations of soft-shelled clams that were fed the toxic dinoflagellate, while it did not affect the respiration rates of adapted populations (Bricelj et al. 2000). Furthermore, reduced respiration rates are consistent with anecdotal and quantitative evidence of incapacitated and lethargic invertebrate grazers from other studies that examined the effects of PSP-producing algae on copepod grazers (Ives 1985, 1987, Huntley et al. 1986, Bagoien et al. 1996, Turner et al. 1998 and references therein, Teegarden 1999).

In contrast to the naïve NJ Acartia hudsonica population, Alexandrium fundyense is not toxic to $\mathrm{ME} A$. hudsonica (Fig. 1). The ME copepods presumably have evolved a resistance to the toxic dinoflagellate (Colin \& Dam 2002a). Previous work with insects has found several mechanisms of evolved resistance to toxins. These mechanisms include: behavioral avoidance; metabolic resistance that increases the rate at which toxins are broken down; and decreased sensitivity to toxins (Taylor 1986). If copepods become resistant to a toxic alga via the first mechanism and develop an ability to recognize and avoid the alga, then the alga becomes a feeding deterrent. Thus, the copepods would cease feeding activity when given the alga as a sole diet and then select against the alga or resume normal feeding when it is given in a mixed diet (Table 1). Other copepod species appear to have this type of adapted response to $A$. fundyense (Turriff et al. 1995, Teegarden 1999). However, ME A. hudsonica ingest $A$. fundyense at high rates regardless of whether it is provided in a sole (Fig. 1) or mixed diet (authors' unpubl. data). Teegarden et al. (2001) similarly found that $A$. hudsonica from Casco Bay, ME, fed readily on $A$. fundyense in natural algal assemblages. Thus, A. fundyense does not appear to be a feeding deterrent to the ME copepods. They appear to have adapted either a tolerance to the toxins or a mechanism to reduce the accumulation of toxins. This non-selective feeding is inconsistent with observations of other calanoid species that clearly select against $A$. fundyense (Teegarden \& Cembella 1996, Teegarden 1999). Thus, it is 
most likely that different copepod species have evolved different mechanisms to resist the effects of $A$. fundyense.

\section{Implications of toxicity on bloom formation}

One goal in studying grazer-harmful alga interactions is to understand how these interactions affect secondary production and the fate of harmful algal blooms. Studies that have modeled the development of algal blooms repeatedly show that grazer feeding and growth rates determine the fate of algal blooms (Roelke 2000 and references therein). Rapid grazer removal rates and grazer growth rates during the early stages of a bloom are most critical in stopping the development of a bloom (Roelke 2000). During these critical early stages, a blooming alga is typically a member of a mixed assemblage. Thus, during the early stages of a bloom, toxic or deterrent algae would affect copepod feeding and growth rates differently. Algae that possess feeding deterrents do not seem to suppress copepod feeding rates when mixed with other species (Table 1). Thus, a feeding deterrent would not reduce the secondary production of grazers during the early stages of a bloom, unless the growth efficiency is significantly decreased. Even if copepods select against the deterrent alga, most studies show that the alga would be ingested along with other prey species (Table 1). However, because a toxic alga affects grazers regardless of whether it exists alone or as part of an assemblage, it will suppress both the feeding (Figs. 1 $\& 2$ ) and growth of the grazer as soon as its concentration enables copepods to ingest a toxic dose. As a result, grazers would not be as effective at suppressing toxic algal blooms as they would be at suppressing the blooms of feeding deterrent algae.

Acknowledgements. We thank Senjie Lin, Eric Schultz, Evan Ward and anonymous reviewers for constructive criticism. Alexandrium strains were supplied by Jennifer Martin (NB-05) and Dave Kulis (ATSW01-1 strain from D. Anderson lab). Gary Wikfors supplied Tetraselmis sp. Sheean Haley measured toxins. To all, we extend our deep gratitude. This research was supported by the ECOHAB program (grants NOAA NA160P1458 and EPA R-826219-01-0) and the Connecticut SeaGrant program (grant NA86RG0043) awarded to H.G.D. and an EPA STAR fellowship (U-91562701-1) awarded to S.P.C.

\section{LITERATURE CITED}

Anderson DM (1997) Bloom dynamics of toxic Alexandrium species in the northeastern US. Limnol Oceanogr 42: 1009-1022

Anderson DM, Chisholm SW, Watras CJ (1983) Importance of life cycle events in the population dynamics of Gonyaulax tamarensis. Mar Biol 76:179-189
Anderson DM, Kulis DM, Doucette GJ, Gallagher JC, Balech E (1994) Biogeography of toxic dinoflagellates in the genus Alexandrium from the northeastern United States and Canada. Mar Biol 120:467-478

Bagoien E, Miranda A, Reguera B, Franco JM (1996) Effects of 2 paralytic shellfish toxin producing dinoflagellates on the pelagic harpacticoid copepod Euterpina acutifrons. Mar Biol 126:361-369

Ban S, Burns C, Castel J, Chandron Y and 19 others (1997) The paradox of diatom-copepod interactions. Mar Ecol Prog Ser 157:287-293

Bricelj VM, MacQuarrie SP, Twarog BM, Trainer VL (2000) Evidence for adaptation to toxins in populations of the softshell clam, Mya areneria, subjected to recurrent toxic blooms. Abstract Symposium on Harmful Algae in the US. Marine Biological Laboratories, Woods Hole, MA

Chesson J (1983) The estimation and analysis of preference and it relationship to foraging models. Ecology 64: 1297-1304

Colin SP, Dam HG (2002a) Latitudinal differentiation in the effects of the toxic dinoflagellate Alexandrium spp. on the feeding and reproduction of populations of the copepod Acartia hudsonica. Harmful Algae 1:113-125

Colin SP, Dam HG (2002b) Testing for toxic effects of prey on zooplankton using sole versus mixed diets. Limnol Oceanogr 47:1430-1437

DeMott WR, Moxter F (1991) Foraging cyanobacteria by copepods: responses to chemical defense and resource abundance. Ecology 72:1820-1834

Durbin EG, Durbin AG (1978) Length and weight relationships of Acartia clausi from Narragansett Bay, RI. Limnol Oceanogr 23:958-969

Engstrom J, Koski M, Viitasalo M, Reinikainen M, Repka S, Sivonen K (2000) Feeding interactions of the copepods Eurytemora affinis and Acartia bifilosa with the cyanobacteria Nodularia sp. J Plankton Res 22:1403-1409

Falconer DS (1996) Introduction to quantitative genetics. Longman, London, p 122-144

Feinberg LR, Dam HG (1998) Effects of diets on dimensions, density and sinking rates of fecal pellets of the copepod Acartia tonsa. Mar Ecol Prog Ser 175:87-96

Frangópulos M, Guisande C, Maneiro I, Riveiro I, Franco J (2000) Short-term and long-term effects of the toxic dinoflagellate Alexandrium minutum on the copepod Acartia clausi. Mar Ecol Prog Ser 203:161-169

Frost BW (1972) Effects of size and concentration of food particles on the feeding behavior of the marine planktonic copepod Calanus pacificus. Limnol Oceanogr 17:805-815

Guillard RRL (1975) Culture of phytoplankton for feeding marine invertebrates. In: Smith WL, Chanley MH (eds) Culture of marine animals. Plenum Press, New York, p 26-60

Hallegraeff GM (1993) A review of harmful algal blooms and their apparent global increase. Phycologia 32:79-99

Huntley ME, Sykes P, Rohan S, Marin V (1986) Chemicallymediated rejection of dinoflagellate prey by the copepods Calanus pacificus and Paracalanus parvus: mechanisms, occurrences, and significance. Mar Ecol Prog Ser 28: $105-120$

Ikeda T (1985) Metabolic rates of epipelagic marine zooplankton as a function of body mass and temperature. Mar Biol 85:1-11

Ikeda T, Torres JJ, Hernandez-Leon S, Geiger SP (2000) Metabolism. In: Harris RP, Wiebe PH, Lenz J, Skjoldal HR, Huntley M (eds) ICES zooplankton methodology manual. Academic Press, New York, p 455-532

Ikeda T, Kanno Y, Ozaki K, Shinada A (2001) Metabolic rates 
of epipelagic marine copepods as a function of body mass and temperature. Mar Biol 139:587-596

Indrasena WM, Gill TA (1999) Thermal degradation of paralytic shellfish poisoning toxins in scallop digestive glands. Food Res Int 32:49-57

Ives JD (1985) The relationship between Gonyaulax tamarensis cell toxin levels and copepod ingestion rates. In: Anderson DM, White AW, Baden DG (eds) Toxic dinoflagellates. Elsevier, New York, p 413-418

Ives JD (1987) Possible mechanisms underlying copepod grazing responses to levels of toxicity in red tide dinoflagellates. J Exp Mar Biol Ecol 112:131-145

Jónasdóttir SH, Kiørboe T, Tang KW, St. John M, Visser AW, Saiz E, Dam HG (1998) The role of diatoms in copepod production: good, harmless or toxic? Mar Ecol Prog Ser 172:305-308

Kiørboe T, Møhlenberg F, Hamburger F (1985) Bioenergetics of the planktonic copepod Acartia tonsa: relation between feeding, egg production and respiration, and composition of specific dynamic action. Mar Ecol Prog Ser 26:85-97

Kirk KL, Gilbert JJ (1992) Variation in herbivore response to chemical defenses: zooplankton foraging on toxic cyanobacteria. Ecology 73:2208-2217

Koski M, Rosenberg M, Viitasalo M, Tanskanen S, Sjölund U (1999) Is Prymnesium patelliferum toxic for copepods? Grazing, egg production and egestion of the calanoid copepod Eurytemora affinis in mixtures of 'good' and 'bad' food. ICES J Mar Sci 56:131-139

Miralto AIA, Poulet SA (1995) Food type induces different reproductive responses in the copepod Centropages typicus. J Plankton Res 17:1521-1534

Nejstgaard JC, Solberg PT (1996) Repression of copepod feeding and fecundity by the toxic haptophyte Prymnesium patelliferum. Sarsia 81:339-344

Oshima Y, Sugino K, Yasumoto T (1989) Latest advances in HPLC analysis of paralytic shellfish toxins. In: Natori S, Hashimoto K, Ueno Y (eds) Mycotoxins and phycotoxins. Proc 7th Int IUPAC Symp. Elsevier, Amsterdam, p 319-326

Roelke DL (2000) Copepod food-quality threshold as a mechanism influencing phytoplankton succession and accumulation of biomass, and secondary productivity: a modeling study with management implications. Ecol Model 134: 245-274

Schatz EJ (1986) Chemistry and biology of saxitoxin and related toxins. Ann New York Acad Sci 479:15-23

Shaw BA, Andersen RJ, Harrison PJ (1997) Feeding deterrent

Editorial responsibility: Thomas Kiørboe (Contributing

Editor), Charlottenlund, Denmark and toxicity of apo-fucoxanthinoids and phycotoxins on a marine copepod (Tigriopus californicus). Mar Biol 128: $273-280$

Sokal RR, Rohlf FJ (1995) Biometry. WH Freeman, San Francisco

Sykes PF, Huntley ME (1987) Acute physiological reactions of Calanus pacificus to selected dinoflagellates: direct observations. Mar Biol 94:19-24

Taylor CE (1986) Genetics and evolution of resistance to insecticides. Biol J Linn Soc 27:103-112

Teegarden GJ (1999) Copepod grazing selection and particle discrimination on the basis of PSP toxin content. Mar Ecol Prog Ser 181:163-176

Teegarden GJ, Cembella AD (1996) Grazing of toxic dinoflagellates, Alexandrium spp., by adult copepods of coastal Maine: implications for the fate of paralytic shellfish toxins in marine food webs. J Exp Mar Biol Ecol 196:145-176

Teegarden GJ, Campbell RG, Durbin EG (2001) Zooplankton feeding behavior and particle selection in natural plankton assemblages containing toxic Alexandrium sp. Mar Ecol Prog Ser 218:213-226

Thor P (2000) Relationship between specific dynamic action and protein deposition in calanoid copepods. J Exp Mar Biol Ecol 245:171-182

Turner JT, Anderson DM (1983) Zooplankton grazing during dinoflagellate blooms in a Cape Cod embayment, with observations of predation upon tintinnids by copepods. Mar Ecol 4:359-374

Turner TT, Tester PA, Hansen PJ (1998) Interactions between toxic marine phytoplankton and metazoan and protistan grazers. In: Anderson DM, Cembella AD, Hallegraeff GM (eds) Physiological ecology of harmful algal blooms. NATO ASI Series, Vol G 41. Springer-Verlag, Berlin, p 453-474

Turriff N, Runge JA, Cembella AD (1995) Toxin accumulation and feeding behavior of the planktonic copepod Calanus finmarchicus exposed to the red-tide dinoflagellate Alexandrium excavatum. Mar Biol 123:55-64

Utermöhl H (1958) Zur Vervollkommnung der qualitativen Phytoplankton-Methodik. Mitt Int Theor Angew Limnol 9:1-38

Walker CH, Hopkin SP, Sibley RM, Peakall DB (2001) Principles of ecotoxicology, 2nd edn. Taylor \& Francis, London

Watras CJ, Garcon VC, Olson RJ, Chisholm SW, Anderson DM (1985) The effect of zooplankton grazing on estuarine blooms of the toxic dinoflagellate Gonyaulax tamarensis. J Plankton Res 7:891-908

Submitted: July 29, 2002; Accepted: October 29, 2002

Proofs received from author(s): February 7, 2003 